\title{
Increase The State Of Poverty In Jordan During The Period 2010-2017
}

\author{
https://doi.org/10.21272/sec.4(4).39-47.2020.
}

\author{
Jameel Aljaloudi, ORCID: https://orcid.org/0000-0002-2924-4119
}

Prof. Dr., Department of Planning and Project Management, College of Business, Al-Balqa Applied University, Jordan

\begin{abstract}
This research aims to study the change in poverty rates in Jordan and the governorates during the period 20102017. In estimating poverty rates, the method used by the government in the report on the state of poverty in Jordan for the year 2012 was adopted. This method is similar to the method of the World Bank in estimating global poverty rates. In assessing poverty lines for the year 2017, poverty lines for the year 2010 were re-estimated based on the change in inflation rates and the change in the standard household size at the national and governorate levels during the period 2010-2017.

The research relied on national and international secondary sources to collect data related to income, economic growth, and unemployment. Mainly, in this research, reference was made to the Household Income and Expenditure Survey for the year 2010 and 2017 that was conducted by the Jordanian Department of General Statistics.

The results of the research showed a significant increase in poverty rates at the national level. It increased from $(14.4 \%)$ in 2010 to $(22.2 \%)$ in 2017 . With the exception of Ma'an Governorate, all governorates showed a significant increase in their poverty rates. The results also showed the great variation in poverty rates between governorates. These results indicate that the goals contained in the government's poverty reduction strategies have not been achieved. The reason is not only due to the content and implementation of these plans, but also to the slowdown in economic growth rates and the high unemployment rates since 2010.

It is also expected that the rise in the state of poverty will continue due to the deterioration of the economic conditions and will continue with the Corona pandemic, the end of which cannot be foreseen. This situation constitutes more pressure on the government to provide appropriate solutions to alleviate the state of poverty, especially in the difficult fiscal conditions it has faced recently.
\end{abstract}

Keywords: poverty, welfare economic, income distribution, economic growth, unemployment.

JEL Classification: J2, J3, J6, O1, R2, R5, O1.

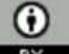

This work is licensed under a Creative Commons Attribution 4.0 International License.

Cite as: Aljaloudi, J. (2020). Increase The State Of Poverty In Jordan During The Period 2010-2017. SocioEconomic Challenges, 4(4), 39-47. https://doi.org/10.21272/sec.4(4).39-47.2020.

(C) The Author, 2020. This article is published with open access at Sumy State University.

\section{Introduction}

Poverty and its alleviation have received attention from international institutions since the 1990s. The United Nations has set the goal of eliminating extreme poverty in the world by 2030. As for Jordan, there is increasing interest in identifying poverty and its rates, and in preparing and implementing the first and second strategies related to poverty reduction in the Kingdom. The Poverty Report in Jordan in 2012 was the last official report prepared by the Department of Statistics. The results of this estimate are based on the 2010 Household Income and Expenditure Survey conducted by the same department. 
Since that time, no official reports have been issued on the development of the state of poverty, and no scientific studies have been conducted in this regard. Despite the Department of Statistics publishing the results of the last survey of household expenditures and incomes that it conducted in 2017, which raised the question of public opinion about the extent of the aggravation. The problem of poverty through the media and the parliament's questions to the government last year, and the government's failure to answer these questions.

The researcher sees the importance of studying the state of poverty based on the results of the last survey in 2017. He believes that the state of poverty has increased at the national level and in the governorates during the period (2010-2017). The continuing slowdown in economic growth rates, high unemployment rates in the Jordanian economy, deteriorating economic and security conditions in the Middle East region, and the negative reflection of the Corona pandemic will inevitably lead to an increase in poverty rates in Jordan.

This study aims to estimate poverty rates in 2017 and compare them with poverty rates in 2010 to show the extent of the increase in poverty during the period 2010-2017. In this study, the method used by the government to estimate absolute poverty lines in 2010 was adopted, and it is the same method used by the World Bank. The same method was used also to estimate poverty lines for the year 2017.

The study relied on secondary sources represented in the results of the field survey of household expenditures and income for the year 2010 and 2017, which were conducted by the Jordanian Department of Statistics. The study, especially with regard to indicators of economic growth and unemployment, was relied on publications and reports of international institutions and websites specialized in the global economic field.

In addition to the introduction, the study consists of the theoretical framework and applied studies in Jordan in the first part, the methodology and data sources in the second part, and the findings and recommendations in the last part.

\section{Theoretical framework and empirical studies}

\subsection{Theoretical framework}

Poverty is no longer an economic phenomenon only, meaning insufficient individual or family income to ensure decent and sustainable livelihoods. Rather, we find that today poverty is a multidimensional phenomenon, according to its definition by the United Nations and the World Bank.

The United Nations defines poverty as: "poverty has various manifestations, including lack of income and productive resources sufficient to ensure sustainable livelihoods; hunger and malnutrition; ill health; limited or lack of access to education and other basic services; increased morbidity and mortality from illness; homelessness and inadequate housing; unsafe environments; and social discrimination and exclusion. It is also characterized by a lack of participation in decision-making and in civil, social and cultural life". (United Nation 2009)

The World Bank's concept of poverty is very similar to the concept of poverty of the United Nations, where the World Bank defined poor people as following: "They often lack adequate food and shelter, education and health, deprivations that keep them from leading the kind of life that everyone values. They also face extreme vulnerability to ill health, economic dislocation and natural disasters. And they are often exposed to ill treatment by institutions of the state and society and are powerless to influence key decision affecting their lives "(World Bank 2001). There are also a number of academic researchers who have similarly explained the phenomenon of poverty. Yekini et al (2012) defined poverty as the opposite of wellbeing. Poverty goes beyond lack of income, but stretches now to include disadvantages in access to land, credit and services, vulnerability, powerlessness and social exclusion. Since poverty is not restricted to material deprivation, other intangible aspects such as poor access to schooling, healthcare and exclusion from decision making processes (Yekini et al, 2012). (Narayan etl 2000) deals with the definition of poverty through the causes leading to it, such as gender, age, culture and other economic and social factors. Poverty in its most general sense is the lack of basic necessities: food; shelter; medical care and safety that are generally thought to be necessary (Bradshaw 2006).

Income or spending for an individual or household is still the most used measure by the World Bank and by developed and developing countries. A poor person is a person (or household) whose income cannot be obtained from a basket of basic used goods and services that ensure a decent living. This basket determines the poverty 
threshold. The monetary value of this basket is the poverty line. Poor people in society are the number of individuals or households whose income is below the poverty line.

The extreme poverty line is the income that guarantees the individual or (household) from purchasing the minimum food basket necessary for life. The absolute poverty line is that income that guarantees the individual or (household) from purchasing the food and non-food basket (food, housing, health, education) ...) guarantee him a decent life in his community.

The extreme poverty line in dollars per day was first introduced in 1990 by the World Bank. Since that time, the World Bank has re-estimated it, taking into account the difference in purchasing power. The last amendment was in 2015 and was estimated at (\$1.9) per day) (Roser and Ospina 2019) (Ferreira et al. (2016).

According to estimates by the World Bank, the number of poor decreased from 1.9 billion people (36\% of the world population) in 1990 to 734 million people (10\% of the world population) in 2015 (see Fig. 1).

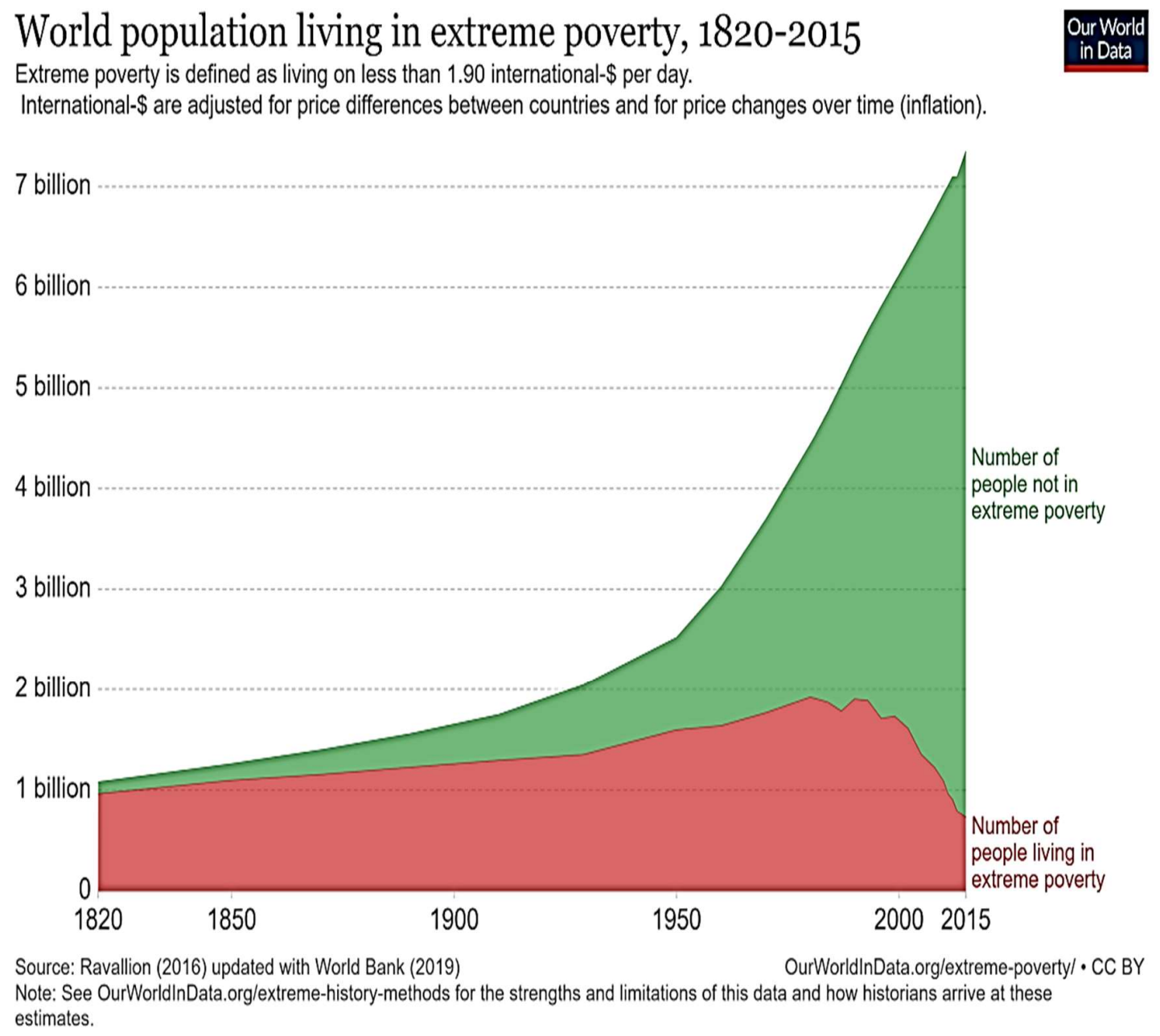

Figure 1. World population living in extreme poverty 1820-2015

Sources: Ravallion (2016) updated with world Bank 2019.

In 2013 the World Bank adopted the following goals: End extreme poverty at the global level and boost shared prosperity in every country in a sustainable way. To achieve the first goal, the bank considers the need to reduce the extreme poverty rate to less than $3 \%$ by 2030 . 
The occurrence of the Corona crisis in 2020 and the failure to predict its end, as well as its negative economic and social impacts in the countries of the world, so the researcher expects an increase in the rate of extreme poverty in the future. The researcher also does not agree with the aspirations of the World Bank to end the state of extreme poverty globally, because the phenomenon of poverty exists in all societies and at all times. Rather, he believes that it is necessary to work on alleviating poverty by adopting strategies and policies to achieve this.

Many countries in the world have adopted the World Bank method for determining their poverty line. Each country has a special threshold for the absolute poverty line. In the United States, for example, the absolute poverty line was estimated at (15.5) dollars per day for each (US Census Bureau. 2011 ), in Jordan (0.65 \$) (UNDP 2013) for each person, and in China (0.55 dollars) (The Government of China 2011) and (Arndt and Trap, 2016).

Relative poverty is another way to measure poverty. It's used by the European Union (Bosch. 2000), Canada, the United Nations Development Program (UNDP 2008) and Economic Cooperation Organization(OECD. 2008). Relative poverty is measured as the percentage of the population whose income is below a constant percentage of the median income. For example, the European Union and the Economic Cooperation Organization adopt a rate (60\%) of the average household income in measuring relative poverty.

\subsection{Empirical studies}

(Dajani and Murdoch, 1978) assessed the basic needs (food, health, education, water and transportation) that the individual had in nine Jordanian villages that were covered by the field survey.

(Al-Suqur et al., 1989) identified pockets of poverty in Jordan and defined the absolute and extreme poverty line for the individual and the family in the governorates of Jordan. They relied in their study on the data of the 1987 Household Expenditure and Income Survey. The study concluded that absolute poverty lines and extreme poverty lines and a variation in poverty rates among the Jordanian governorates were found.

In 2010, the Department of Statistics of Jordan (DOSJ) prepared a report on the state of poverty in Jordan. In analyzing the phenomenon of poverty, the department relied on the results of the Household Income and Expenditure Survey that was conducted by (DOSJ) in 2008. In 2010, the Department of Statistics prepared a report on the state of poverty in Jordan. In analyzing the phenomenon of poverty, the department relied on the results of the household income and expenditures survey that was conducted by it in year 2008. The results showed that the poverty line rate reached (13.3\%), and the absolute poverty line per person per year was (680 dinars) and for the standard household (5.7 persons) 3876 dinars annually estimated. The results of the report also showed the variation in poverty rates between governorates. Where the governorate of Mafraq recorded the highest rate of poverty (31.9\%) and the governorate of Amman the lowest rate of poverty (8.3\%). The report also identified pockets of poverty in Jordan (the districts in which the percentage of individuals below the absolute poverty line exceeds $25 \%$ of the population of the same district). Its number reached 32 pockets.

In 2012, the (DOSJ) prepared another report on the situation of poverty in Jordan, based on the results of the 2010 Household Income and Expenditure Survey (this survey was conducted by (DOSJ) . The results of the report showed an increase in the poverty rate in Jordan. Where it reached (14.4\%). The poverty line per person was estimated at $(813.7$ dinars) per year, and for a standard household whose size was $(5.4$ persons) $(4,394)$ dinars per year.

The report's findings also indicate the regional variation in poverty rates in Jordan. Ma'an Governorate recorded the highest poverty rate $(26.6 \%)$ instead of Mafraq governorate, and Amman Governorate still had the lowest poverty rate $(11.4 \%)$.

Ministry of Planning and International Cooperation (MOPIC) and others 2011) launched a social data pilot survey to measure vulnerability risk and social exclusion. The findings of this report at the macro level analyze the shifts in poverty pockets and the determinants of change in the incidence of poverty during the period 2006-2008. More than $60 \%$ of the variance in the change in the poverty rate in the 36 pockets of poverty is explained by the following factors: 1) the rate of food inflation during the period 2006-2008 at the governorate level, 2) the change in the unemployment rate during the period 2006-2008 in the governorate. Level, 3) the change in the ratio of transferred income to total income at the pocket level from 2006 to 2008,4 ) the growth rate of livestock holdings. At the micro level, a 
comparative study of household behavior inside and outside poverty pockets in relation: to food security and living standards, labor market dynamics, income status, income shocks and precautionary savings, access to transportation, access to health and care for the disabled, get a quality education for children, social exclusion and time use of families, and formal and informal cash transfers.

(Shahateet 2019) has published his study, which aims to determine whether the poor have become poorer in Jordan. The author used the statistical approach to provide critical comparisons, over time, of the proportions of the poor, using primary data from four national surveys (household spending and income) conducted in the following years: 2002, 2006, 2008 and 2010). The results of the statistical tests showed that the poor did not become less poor except in the governorates, while the percentage of the poorest remained less than $10 \%$ of the population.

The originality of this study stems from the fact that it measures the change in poverty rates at the national and governorate levels during the period of time (2010-2017), which was not covered by previous studies. For the researcher's knowledge, no official body or any of the researchers analyzed the results of the last field survey (Household Income and Expenditure Survey in 2017), which was conducted by the Jordanian Department of Statistics. The importance of this study stems from the fact that it measures the success or failure of the successive Jordanian governments to reduce poverty rates, which were the main goal of the poverty reduction strategy (UNDP 2013). It also highlights the relationship between slowing economic growth rates and increasing unemployment rates on the one hand and high unemployment rates during the study period.

\section{Data and Methodology}

In this study, data of the Household Income and Expenditure Survey 2010, 2017 were used. These surveys were conducted by the Department of Statistics in Jordan in 2010 and 2017. In addition to their use of other secondary sources, which were reports and publications of international institutions (the World Bank and the United Nations Development Program) and Jordanian ministries. Books and articles published in the field of poverty were also reviewed for writing this research paper.

To calculate poverty lines at the national and regional levels, the same methodology used by the Jordanian Department of Statistics was adopted in 2010. As for the estimation of poverty lines in 2017, the poverty lines calculated in 2010 were re-estimated, taking into account inflation rates during the period 2010-2017 and the change in the size of the Jordanian family at the national level and in each of the twelve Jordanian governorates.

Table 1. Estimated poverty lines in Jordan by governorates in 2010 and 2017( Jordanian Dinar)

\begin{tabular}{|l|c|c|}
\hline \multicolumn{1}{|c|}{ The Governorates } & Poverty line 2017 (JD) & Poverty line 2010 (JD) \\
\hline Amman & 4454.2 & 4120.1 \\
\hline Al-Balqa & 4919.1 & 4550.2 \\
\hline A-Zarqa & 4850.2 & 4486.4 \\
\hline Maddaba & 4850.2 & 4486.2 \\
\hline Irbid & 4919.1 & 4550.2 \\
\hline Al-Mafraq & 5444.1 & 5035.7 \\
\hline Jarash & 5147.2 & 4761.2 \\
\hline Ajjloun & 4919.1 & 4550.2 \\
\hline Al-Karak & 5048.1 & 4669.2 \\
\hline Al-Tafeelah & 5048.1 & 4669.4 \\
\hline Maan & 5147.2 & 4761.2 \\
\hline Aqaba & 4919.1 & 4550.2 \\
\hline Jordan & 4751.2 & 4393.1 \\
\hline
\end{tabular}

Sources: The Author.

Determining the absolute poverty rate, which is called the head counting index, is by dividing the number of poor people whose income is below the poverty line into the total population at the national level, and in the same way it is calculated for each governorate. Poverty Rate $=$ Number of Poor People $/$ Total Population 


\section{The Result}

The data in Table 2 show that the state of poverty in Jordan worsened during the period (2010-2017). The poverty rate at the national level increased from (14.4\%) in year 2010 to $(22.2 \%)$ in year 2017. With the exception of Ma'an, all governorates in Jordan recorded an increase in the level of poverty during the study period. This does not mean that the state of poverty in this governorate is low. In fact, the rate is still close to the national average, as it is estimated at $(20.1 \%)$. This result does not change much in the general picture at the national level if we take into account that the proportion of the population in this governorate constitutes (DOSJ 2020) of the total population in Jordan.

Table 2 . The poverty rates by governorate in Jordan in 2010 and 2017

\begin{tabular}{|c|c|c|c|}
\hline The Governorates & Poverty Rate 2017 (\%) (1) & Poverty Rate 2010 (\%) (2) & The change in poverty \\
\hline Amman & 21.6 & 11.4 & + \\
\hline Al-Balqa & 24.1 & 20.9 & + \\
\hline A-Zarqa & 24.6 & 14.1 & + \\
\hline Maddaba & 22.7 & 15.1 & + \\
\hline Irbid & 22.1 & 15.0 & + \\
\hline Al-Mafraq & 20.2 & 19.2 & + \\
\hline Jarash & 27.1 & 20.3 & + \\
\hline Ajjloun & 26.5 & 25.6 & + \\
\hline Al-Karak & 24.8 & 13.4 & + \\
\hline Al-Tafeelah & 21.9 & 17.2 & + \\
\hline Maan & 20.1 & 26.6 & - \\
\hline Aqaba & 24.8 & 19.2 & + \\
\hline Jordan & 22.2 & 14.4 & + \\
\hline
\end{tabular}

Figure 2 shows the great variation in poverty rates between governorates on the one hand, and the difference in their ranking in terms of poverty rates on the other hand. Ma'an Governorate and Ajloun Governorate were the poorest in 2010, while in 2017 the governorates of Mafraq, Jarash, Ajloun, and Maan are the poorest in Jordan.

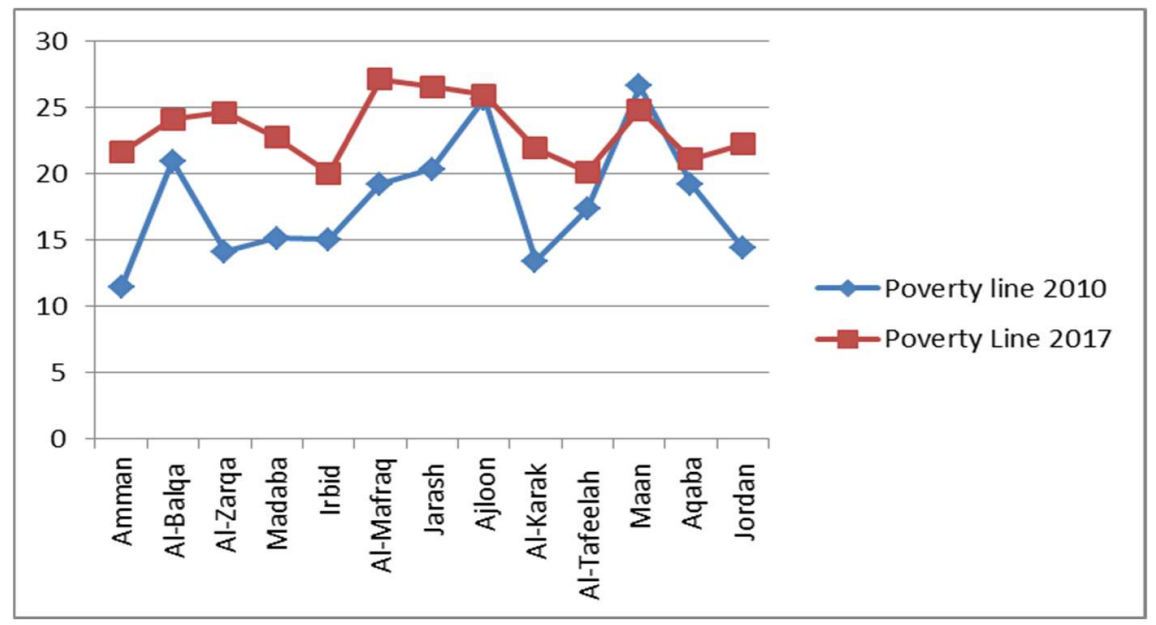

Figure 2. The Change on Poverty Rate in Jordan by Governorate during 2010-2017

Sources: The Author.

It can also be concluded that the high rates of poverty during the study period mean that the first and second poverty reduction strategy has not succeeded in achieving their goals, which are to contain and reduce poverty in Jordan. This failure can be attributed not to the content of these strategies and programs emanating from them, but to the negative economic and social developments that the Jordanian economy is going through, represented 
by slowing economic growth rates, high unemployment rates, high public budget deficits, and deteriorating economic and security conditions in the Middle East region.

Figure 3 shows the decline in real GDP growth rates during the period 2010-2018. While these rates were very high before the year 2010. And if we take into account that the population growth rates were greater or equal in some years than the real growth rates of the GDP, this leads to a decrease in the average per capita income and thus affects the slide of a number of individuals and households into poor class.

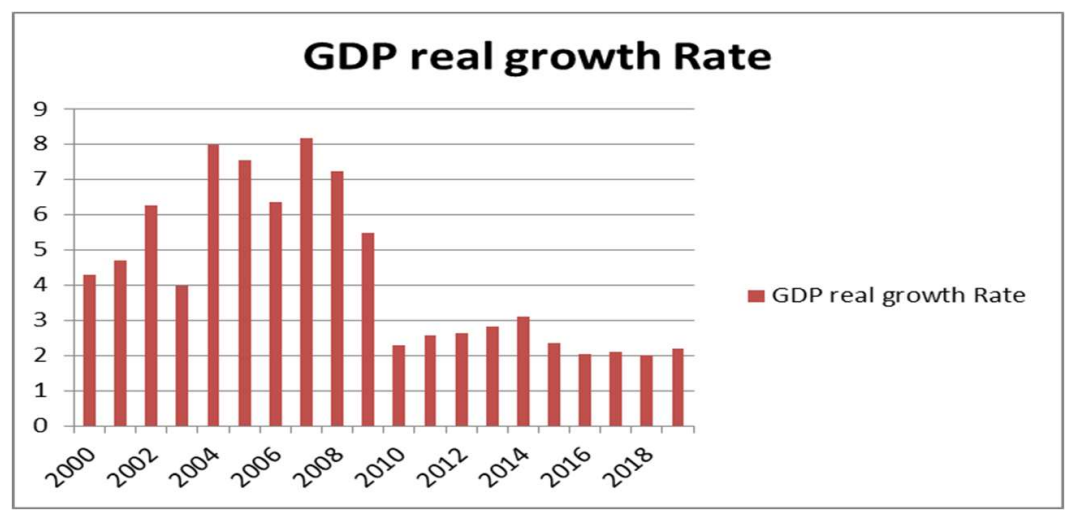

Figure 3. Annual GDP real growth Rate (2000-2018)

Sources: Index Mundi 2020. https://www.indexmundi.com/g/g.aspx?c=jo\&v=66.

The decrease in the real growth rates of the gross domestic product during the period (2010-2018) means, in other words, the inability of the economy to generate sufficient job opportunities to absorb the workforce, which means the continuous rise in unemployment rates. Increasing unemployment means depriving a large number of individuals and households of the income necessary for a decent living, and thus increasing the number of poor people in society. This explains the coincidence of high poverty rates and high unemployment rates (see Figure 4).

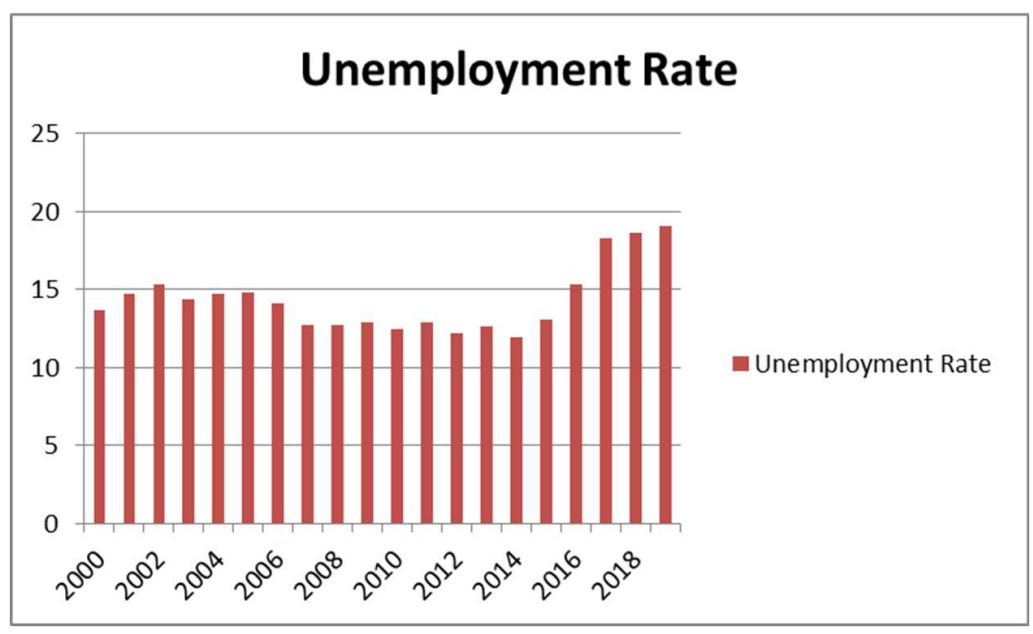

Figure 4. Unemployment Rate in Jordan during 2000-2018

Sources: Statista 2020: https://www.statista.com/statistics/385565/unemployment-rate-in-jordan/.

The continuing deterioration of the economic and security conditions in the Arab countries surrounding Jordan leads to more negative pressures on economic growth, on foreign job opportunities for Jordanians, and on the financial aid that Jordan receives from these countries, especially the Gulf countries. 
The researcher believes that the state of poverty in Jordan will worsen, especially after the Corona pandemic. This pandemic negatively affected economic growth through the partial or complete suspension of a number of projects in all economic sectors. Laying off large numbers of workers in these projects or reducing their wages in half, i.e. partial or total loss of their income and increasing the number of the unemployed. As the recent official reports show an increase in the unemployment rate in the second quarter of 2020 to (23\%) (Dos 2020), the picture becomes more negative as the government cuts support programs and the social safety net to divert public spending to fighting the pandemic and securing the necessary health care for society.

\section{Conclusion and recommendation}

The research concludes with the inability of successive governments to achieve the goals of poverty reduction strategies in Jordan. Rather, we see an increase in the severity of poverty in all Jordanian governorates.

The researcher recommends that governments should take economic programs and policies that address the causes of the phenomenon, that is, work to encourage economic growth and create productive job opportunities through:

$>$ Encouraging internal and external investment and providing financial and technical incentives that are blamed for that

$>$ Involving the private sector in the development process and enabling it to play its developmental role

$>$ Supporting economic projects that create more job opportunities

$>$ Continuing to develop the educational and health infrastructure that qualifies people to work efficiently and effectively

$>$ Supporting poor families in establishing income-generating projects and for work, and giving this form of initial support on monthly financial support, such as support for the National Aid Fund, i.e. creating productive rather than consuming families

$>$ Ensuring adequate financial allocations in the general budget to protect the social safety net, even in light of the difficult public financial circumstances that the country is going through.

$>$ Create a culture of productive work for the citizen instead of waiting to find a job opportunity in the public sector.

$>$ Focusing on applied education and vocational training to enable individuals to work in productive sectors.

Funding: self-funded.

Author Contributions: conceptualization, Jameel Aljaloudi; data curation, Jameel Aljaloudi; formal analysis, Jameel Aljaloudi; funding acquisition, Jameel Aljaloudi; investigation, Jameel Aljaloudi; methodology, Jameel Aljaloudi; project administration, Jameel Aljaloudi; resources, Jameel Aljaloudi; software, Jameel Aljaloudi; supervision, Jameel Aljaloudi; validation, Jameel Aljaloudi; visualization, Jameel Aljaloudi; writing - original draft, Jameel Aljaloudi; writing - review \& editing, Jameel Aljaloudi.

\section{References}

1. Arndt, C and Trap, F. (2017). Measuring Poverty and wellbeing in developing countries. Published to Oxford Scholarship Online 2017, DOI: 10.103/acprof:oso /7801.001.001. Available at: https://oxford. universitypressscholarship.com/.

2. Bradshaw, K. (2006). Theories of Poverty and Anti-Poverty Programs in Community Development. Rural Poverty Research Centre Working Paper No. 06-05, January. Available at: https://www.tandfonline.com/doi/abs/10.1080/15575330709490182

3. Dajanj and Mardock (1987). Assesssing basic human needs in rural Jordan. USAID contractno.aid1987. ( unpublished report).

4. Department of Statistic (2020). Jordan: Unemployment rate for Jordanians Q2, 2020. Available at: http://dosweb.dos.gov.jo/ar/.

5. Department of Statistic (2018). Jordan: Household Income and expenditure survey, 2017. Available at: Available at: http://dosweb.dos.gov.jo/ar/economic/expenditures-income/expend tables/. 
6. Department of Statistic (2010). Household Income and expenditure survey 2010. Available at: http://dosweb.dos.gov.jo/ar/economic/expenditures-income/expend tables/.

7. Department of Statistic (2012). Poverty Report 2010, Table 8, P: 35. Available at: http://www.dos.gov.jo/dos_home_a/main/Analasis_Reports/poverty_rep/poverty report_2010.pdf.

8. Ferriera et al.(2016). The advertisement call and geographic distribution of Proceratophrys dibernardoi Zootaxa". Available at: https://www.researchgate.net/publication/324227283 Ferreira et al 2016 The advertisement call and geographic distribution of Proceratophrys d.

9. Index Mundi (2020). Available at: https://www.indexmundi.com/g/g.aspx?c=jo\&v=66.

10. Max Roser and Esteban Ortiz-Ospina (2019). Global Extreme Poverty. Available at: https://ourworldindata.org/extreme-poverty.

11. Narayan, D., R. Patel, K., Schafft, A., Rademacher, and S., Koch-Schulter (2000). Voices of the Poor: Can Anyone Hear Us? Oxford University Press for the World Bank, New York. Available at: http://www.sciepub.com/reference/115119.

12. OECD (2008). Growing Unequal: Income Distribution and Poverty in OECD Countries. Available at: http://www.oecd.org/els/soc/41527936.pdf.

13. Ravallion, M. (2017). Poverty comparisons. London: Routledge. Available at: https://www.taylorfrancis.com/books/ 9780203985328

14. Statista (2020). Available at: https://www.statista.com/statistics/385565/unemployment-rate-in-jordan/.

15. The Government of China (2011). New Progress in Development-oriented Poverty Reduction Program for Rural China $(1,274$ yuan per year $=$ US\$ 0.55 per day). Available at: https://en.wikipedia.org/wiki/Poverty\#cite note-24.

16. UNDP (2008). Human development report: Capacity development: Empowering people and institutions (Report). Available at: https://www.undp.org/content/undp/en/home/librarypage/ corporate/ undp in action 2008.html.

17. UNDP (2013). Jordan Poverty Reduction Strategy Final Report". Available at: https://www.undp.org/content/dam/jordan/docs/Poverty/Jordanpovertyreductionstrategy.pdf.

18. (United Nation 2009). Chapter 8 - Poverty. Available at: Social/products/Poverty BW.pdf.

19. US Census Bureau (2011). Poverty Definitions. Archived from the original on 6 February 2016. Retrieved 20 December 2017. Available at: https://en.wikipedia.org/wiki/Poverty\#cite note-24.

20. World Bank (2001). World Development Report 2000/2001: Attacking Poverty. World Development Report; New York: Oxford University Press. Available at: https://openknowledge.worldbank.org/ handle/ 10986/11856.

21. Yekini, N., M., Rufai, B., Adetoba, A., Akinwole, and O., Ojo (2012). ICT Tools for Poverty Eradication and Economic Growth in Nigeria. Greener Journal of Education Research, 2 (1), 13-19. Available at: https://www.researchgate.net/publication/313320296 Ict Tools for Poverty Eradication and Economic Growth in Nigeria. 